\title{
DNA methylation is associated with lung function in never smokers
}

\author{
Maaike de Vries ${ }^{1,2^{*}}$ (D), Ivana Nedeljkovic ${ }^{3}$, Diana A. van der Plaat ${ }^{1,2}$, Alexandra Zhernakova ${ }^{4}$, Lies Lahousse ${ }^{3,5}$, \\ Guy G. Brusselle $3,6,7$, BIOS Consortium ${ }^{8}$, Najaf Amin ${ }^{3}$, Cornelia M. van Duijn ${ }^{3}$, Judith M. Vonk ${ }^{1,2}$ and \\ H. Marike Boezen ${ }^{1,2}$
}

\begin{abstract}
Background: Active smoking is the main risk factor for COPD. Here, epigenetic mechanisms may play a role, since cigarette smoking is associated with differential DNA methylation in whole blood. So far, it is unclear whether epigenetics also play a role in subjects with COPD who never smoked. Therefore, we aimed to identify differential DNA methylation associated with lung function in never smokers.

Methods: We determined epigenome-wide DNA methylation levels of 396,243 CpG-sites (Illumina $450 \mathrm{~K}$ ) in blood of never smokers in four independent cohorts, LifeLines COPD\&C ( $N=903)$, LifeLines DEEP $(N=166)$, Rotterdam Study (RS)-III ( $N=150)$ and RS-BIOS ( $N=206)$. We meta-analyzed the cohort-specific methylation results to identify differentially methylated $\mathrm{CpG}$-sites with FEV 1 /FVC. Expression Quantitative Trait Methylation (eQTM) analysis was performed in the Biobank-based Integrative Omics Studies (BIOS).

Results: A total of $36 \mathrm{CpG}$-sites were associated with $\mathrm{FEV}_{1} / \mathrm{FVC}$ in never smokers at $p$-value $<0.0001$, but the metaanalysis did not reveal any epigenome-wide significant CpG-sites. Of interest, 35 of these $36 \mathrm{CpG}$-sites have not been associated with lung function before in studies including subjects irrespective of smoking history. Among the top hits were cg10012512, cg02885771, annotated to the gene LTV1 Ribosome Biogenesis factor (LTV1), and cg25105536, annotated to Kelch Like Family Member 32 (KLHL32). Moreover, a total of 11 eQTMS were identified.

Conclusions: With the identification of $35 \mathrm{CpG}$-sites that are unique for never smokers, our study shows that DNA methylation is also associated with $\mathrm{FEV}_{1} / \mathrm{FVC}$ in subjects that never smoked and therefore not merely related to smoking.
\end{abstract}

Keywords: DNA methylation, Never smokers, FEV $1 / F V C$, EWAS, COPD

\section{Background}

Chronic Obstructive Pulmonary Disease (COPD) is a progressive inflammatory lung disease characterized by persistent airway obstruction that causes severe respiratory symptoms and poor quality of life [1]. Although smoking is generally considered the main environmental risk factor, estimations are that $25-45 \%$ of patients with COPD have never smoked [2]. Despite extensive research, the etiology of COPD remains incompletely understood. It is known

\footnotetext{
* Correspondence: m.de.vries04@umcg.nl

${ }^{1}$ University of Groningen, University Medical Center Groningen, Department of Epidemiology, Hanzeplein 1, 9713 GZ Groningen, The Netherlands

${ }^{2}$ University of Groningen, University Medical Center Groningen, Groningen Research Institute for Asthma and COPD (GRIAC), Groningen, The Netherlands

Full list of author information is available at the end of the article
}

that the development of this complex heterogeneous disease is influenced by both genetic and environmental factors, as well as their interactions [3-6]. As interface between the inherited genome and environmental exposures, an important role has been postulated for the epigenome [7]. The epigenome includes multiple epigenetic mechanisms that affect gene expression without modifying the DNA sequence. These epigenetic mechanisms are highly dynamic and respond to environmental exposures, ageing and diseases [8]. One such epigenetic mechanism is DNA methylation, which involves the binding of a methyl group to a cytosine base located adjacent to a guanine base. Methylation of these so called CpG-sites in regulatory regions of the DNA generally result in decreased expression of a particular gene [9].

(C) The Author(s). 2019 Open Access This article is distributed under the terms of the Creative Commons Attribution 4.0 International License (http://creativecommons.org/licenses/by/4.0/), which permits unrestricted use, distribution, and 
So far, only a few studies have investigated the association between DNA methylation in peripheral blood and COPD or lung function using an epigenome-wide hypothesis free approach [10-17]. Although findings across the studies are not consistent, there is suggestive evidence that alterations in DNA methylation might play a role in the etiology of COPD. However, in previous studies, subjects were mainly included irrespective of smoking status, thus including current smokers, ex-smokers and never smokers. As a consequence, it is currently not known if there are differences in DNA methylation between healthy individuals and patients with COPD who have never smoked. Recently, we studied the association between epigenome-wide DNA methylation and COPD in both current smokers and never smokers [16]. Although we did not find any epigenome-wide significant association in current smokers nor in never smokers, the associations between DNA methylation and COPD were different between both groups. Hence, by further exploring the role of DNA methylation in a much larger set of never smokers together with a continuous measurement of lung function, we might be able to reveal important novel insights in the etiology of COPD. In this study, we aim to assess the association between DNA methylation and lung function in never smokers, meta-analyzing four independent population-based cohorts.

\section{Methods}

\section{Study population}

To study the association between epigenome-wide DNA methylation and lung function, defined as the ratio between the Forced Expiratory Volume in $1 \mathrm{~s}\left(\mathrm{FEV}_{1}\right)$ and Forced Vital Capacity (FVC), in never smokers, we performed a meta-analysis in four different cohorts. Two cohorts originated from the LifeLines population-based cohort study [18]: the LifeLines COPD \& Controls DNA methylation study $[16,19]$ (LL COPD\&C, $n=903$ ) and the LifeLines DEEP study [20] (LLDEEP, $n=166$ ). The two other cohorts originated from the population-based Rotterdam study (RS) [21]: The first visit of the third RS cohort (RS-III-1, $n=150$ ) and a cohort selected for the Biobank-based Integrative Omics Studies (BIOS) project (RS-BIOS, $n=206$ ). Both population-based cohort studies were approved by the local university medical hospital ethical committees and all participants signed written informed consent. In all cohorts, never smoking was defined based on self-reported never smoking history and 0 pack years included in the standardized questionnaires.

\section{Measurements \\ Lung function}

Within the LifeLines population-based cohort study, prebronchodilator spirometry was performed with a Welch Allyn Version 1.6.0.489, PC-based Spiroperfect with CA Workstation software according to ATS/ERS guidelines. Technical quality and results were evaluated by well-trained assistants and difficult to interpret results were re-evaluated by a lung physician. Within the population-based Rotterdam study, pre-bronchodilator spirometry was performed during the research center visit using a SpiroPro portable spirometer (RS-III-1) or a Master Screen PFT Pro (RS-BIOS) by trained paramedical staff according to the ERS/ATS Guidelines. Spirometry results were analyzed by two researchers and verified by a specialist in pulmonary medicine.

\section{DNA methylation}

In all four cohorts, DNA methylation levels in whole blood were determined with the Illumina Infinium Methylation $450 \mathrm{~K}$ array. Data was presented as beta values (ratio of methylated probe intensity and the overall intensity) ranging from 0 to 1 . Quality control has been performed for all datasets separately as described before [19, 22]. After quality control, data was available on 396,243 CpG-sites in all four datasets.

\section{Statistical analysis}

\section{Epigenome-wide association study and meta-analysis}

We performed an epigenome-wide association study (EWAS) on lung function defined as $\mathrm{FEV}_{1} / \mathrm{FVC}$ in all four cohorts separately using robust linear regression analysis in R. The analysis was adjusted for the potential confounders age and sex. To adjust for the cellular heterogeneity of the whole blood samples, we included proportional white blood cell counts of mononuclear cells, lymphocytes, neutrophils and eosinophils, obtained by standard laboratory techniques. For LL COPD\&C, we adjusted for technical variation by performing a principal components analysis using the 220 control probes

Table 1 Subject characteristics of the subjects from the four different DNA methylation datasets

\begin{tabular}{|c|c|c|c|c|}
\hline & LL COPD\&C & LLDEEP & RS-III-1 & RS-BIOS \\
\hline Number of subjects, N (\%) & 903 & 166 & 150 & 206 \\
\hline Male, N (\%) & $508(56.3)$ & $71(42.8)$ & $74(49.3)$ & $80(38.8)$ \\
\hline Age (yrs), median (min-max) & $46(18-80)$ & $42(20-78)$ & $63(53-93)$ & $68(52-79)$ \\
\hline Airway obstruction ( $\left.\mathrm{FEV}_{1} / \mathrm{FVC}<70 \%\right)$, N (\%) & $316(35.0)$ & $15(9.0)$ & $13(8.7)$ & $19(9.0)$ \\
\hline - $\mathrm{FEV}_{1}(\mathrm{~L})$, mean $(\mathrm{SE})$ & $3.5(0.9)$ & $3.6(0.9)$ & $3.2(0.8)$ & $2.7(0.7)$ \\
\hline - $\mathrm{FEV}_{1} / \mathrm{FVC}$, mean (SE) & $84.5(8.2)$ & $78.6(6.2)$ & $77.8(5.9)$ & $77.9(5.9)$ \\
\hline
\end{tabular}




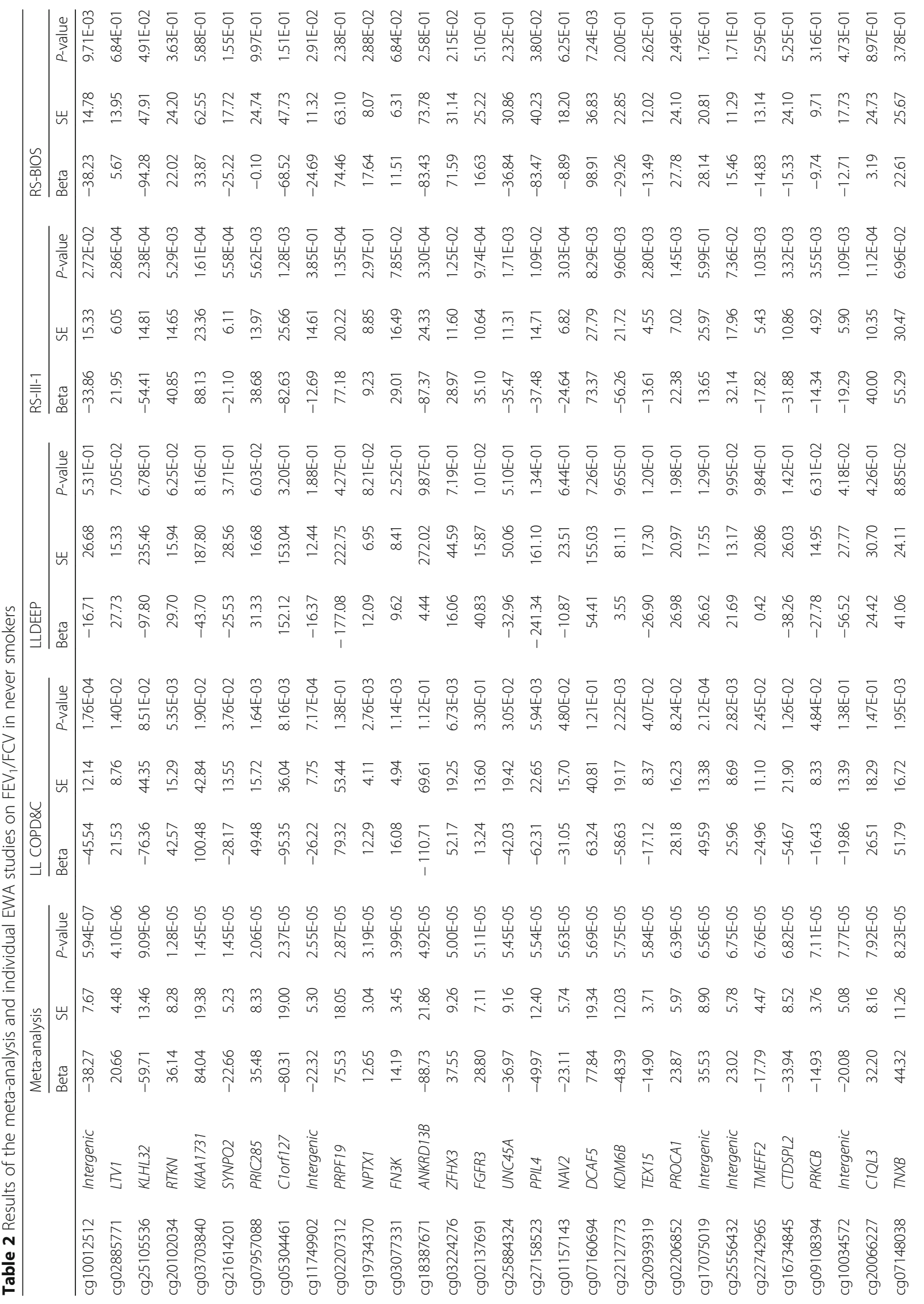




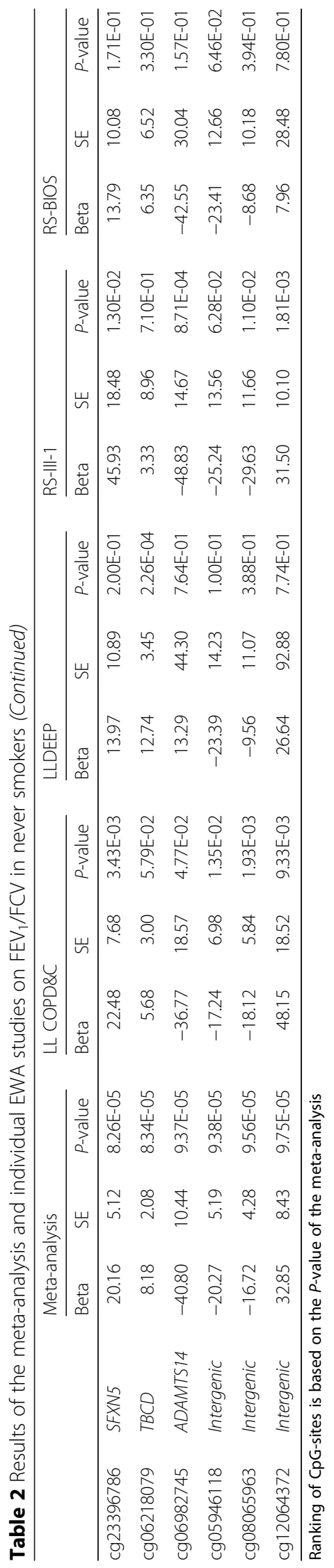




\section{A}

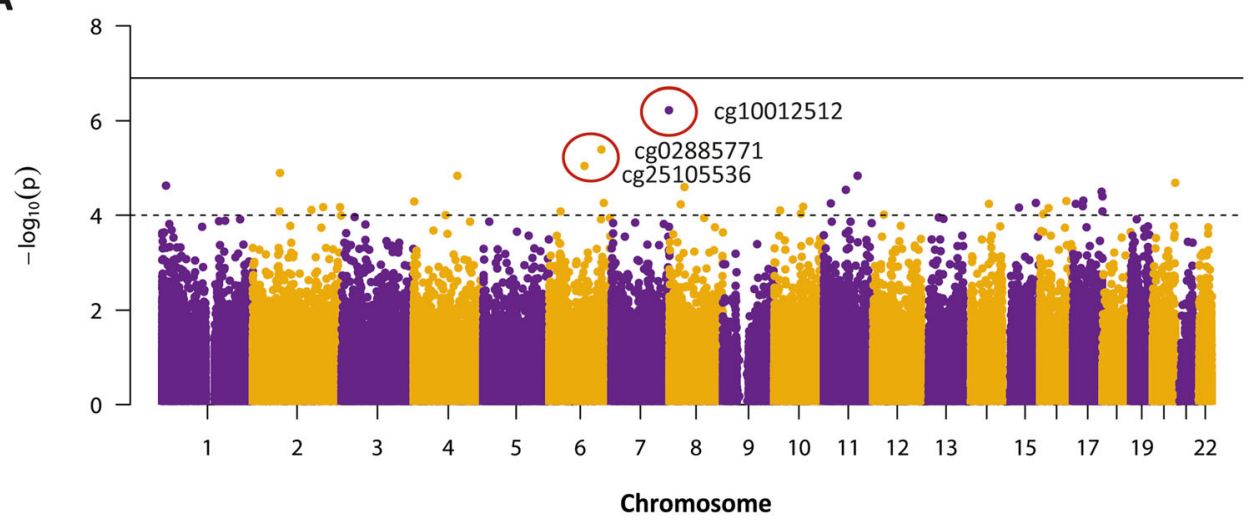

B

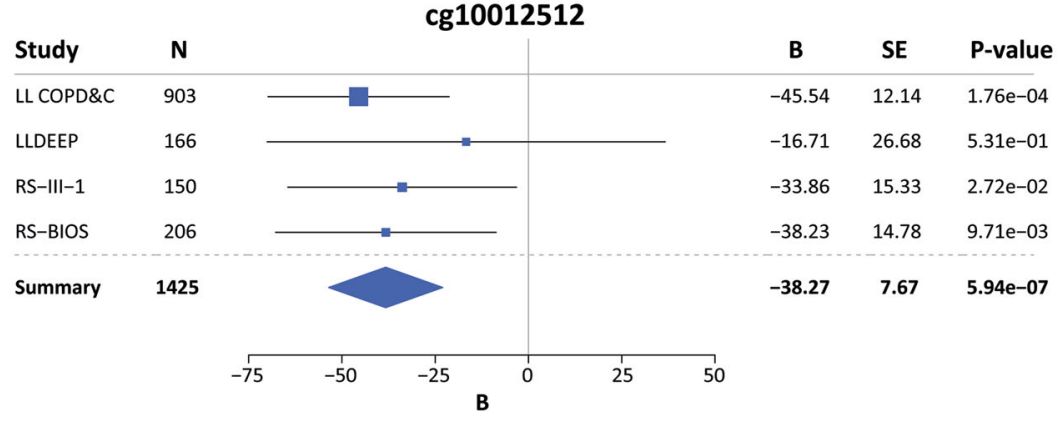

C

$\operatorname{cg} 02885771$

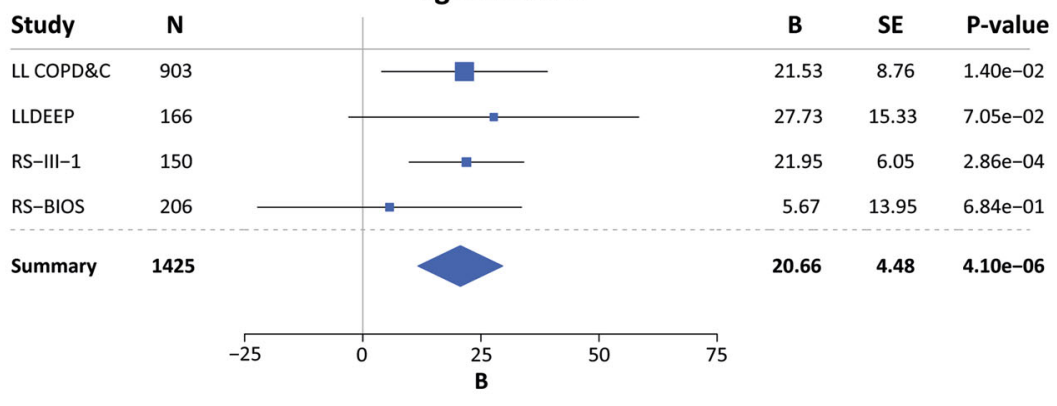

D

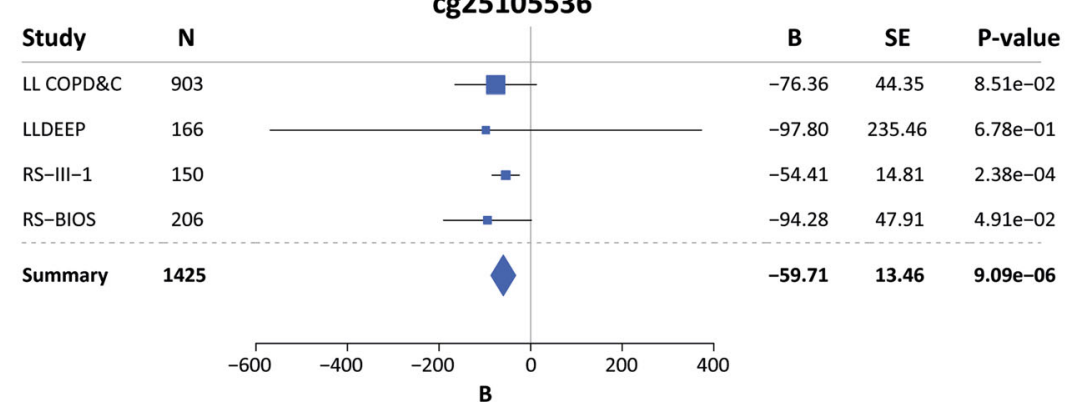

Fig. 1 Manhattan and forest plots of the meta-analysis on four independent epigenome-wide association studies on $\mathrm{FEV}_{1} / \mathrm{FVC}_{\mathrm{C}}$ in never smokers. a Manhattan plot in which every dot represents an individual CpG-site. Location on the X-axis indicated the chromosomal position and location on the $Y$-axis indicates the inversed log [10] $p$-value of the meta-analysis. Dotted horizontal line indicates $p$-value of 0.0001 , horizontal fixed line indicates epigenome-wide significance $\left(p\right.$-value $\left.<0.05 / 396,243=1.26 \times 10^{\wedge^{-7}}\right)$. $\mathbf{b}$-d Forest plots showing the effect estimates and standard errors of the 4 independent EWA studies and meta-analysis for the top hits cg10012512 (b), cg028885771 (c) and cg25105536 (d) 
incorporated in the Illumina $450 \mathrm{k}$ Chip. The 7 principal components that explained $>1 \%$ of the technical variation were included in the analysis. For LLDEEP, data on technical variance was not accessible. For the two RS cohorts, we included the position on the array and array number to adjust for technical variation. Regression estimates from all four individual EWA studies were combined by a weighted by the inverse of the variance random-effect meta-analysis using the effect estimates and standard errors in "rmeta" package in R. CpG-sites with a $p$-value below $1.26 \times 10^{\wedge-7}$ (Bonferroni corrected $p$-value by number of CpG-sites $0.05 / 396243)$ were considered epigenome-wide significant. CpG-sites with a $p$ value below 0.0001 in the meta-analysis were defined as top associations in our study.

\section{Expression quantitative trait methylation (eQTM) analysis}

To assess whether top associations were also associated with gene expression levels, we used the never smokers included in the Biobank-based Integrative Omics Studies (BIOS). For all cohorts separately, reads were normalized to counts per million. To adjust for technical variation for gene expression and DNA methylation, principal component analysis was conducted on the residual normalized counts and beta-values excluding the potential confounders age and gender. Principal components that explained more than $5 \%$ of the technical variation in gene expression or DNA methylation were included in the analysis. Subsequently, robust linear regression analysis was performed on the $\mathrm{CpG}$-sites and the genes within $1 \mathrm{MB}$ around the CpG-sites. The analyses were adjusted for the potential confounders age, sex and technical variation by principal components as stated before. The individuals eQTM analysis were combined by a random-effect meta-analysis using the effect estimates and standard errors in RMeta. An eQTM was considered significant when the Bonferroni-adjusted $p$-value for the number of genes within $1 \mathrm{MB}$ around the CpGsites was below 0.05 .

\section{Results}

Subject characteristics

An overview of the characteristics of the subjects included in the study is shown in Table 1. LL COPD\&C was the largest cohort included in this meta-analysis. Notably, since this cohort is a non-random selection from the LifeLines cohort study with COPD (defined as $\mathrm{FEV}_{1} / \mathrm{FVC}<$ 0.70 ) as one of the selection criteria, the percentages of COPD cases should not be interpreted as prevalence.

\section{Meta-analysis of the four epigenome-wide association studies}

The meta-analysis of the four different cohorts did not reveal CpG-sites that were epigenome wide significantly associated with $\mathrm{FEV}_{1} / \mathrm{FVC}$. We identified $36 \mathrm{CpG}$-sites as our top associations (Table 2). The Manhattan plot of the meta-analysis is shown in Fig. 1a. Forest plots of the three most significant CpG-sites cg10012512, located in the intergenic region of chromosome 7q36.3 $\left(p=5.94 \times 10^{\wedge^{-7}}\right)$, cg02285771, annotated to LTV1 Ribosome Biogenesis Factor (LTV1) $\left(p=4.10 \times 10^{\wedge^{-6}}\right)$ and cg25105536, annotated to Kelch Like Family Member 32 (KLHL32) ( $p=$ $9.09 \times 10^{\wedge^{-6}}$ ) are shown in Fig. 1b-d. An overview of all CpG-sites associated with $\mathrm{FEV}_{1} / \mathrm{FVC}$ at nominal $p$-value of 0.05 can be found in Additional file 1: Table S1.

The direction of the effect of the 36 top CpG-sites did not change in a sensitivity analysis in the LL COPD\&C cohort excluding the subjects that were exposed to environmental tobacco smoke (ETS) $(N=659$ subjects) (Additional file 2: Table S2).

Expression quantitative trait methylation (eQTM) analysis In total, 803 genes were located within $2 \mathrm{MB}$ of the 36 CpG-sites. The expression of 11 genes was significantly

Table 3 Overview of the results of the meta-analysis of the eQTM analysis

\begin{tabular}{llllllll}
\hline CpG-site & $\begin{array}{l}\text { Gene annotation } \\
\text { CpG-site }\end{array}$ & $\begin{array}{l}\text { Genes located } \\
\text { within 1 MB (N) }\end{array}$ & Gene (expression) & Beta & SE & $p$-value & Adjusted $p$-value \\
\hline cg02137691 & FGFR3 & 31 & SLC26A1 & 0.0156 & 0.0038 & $3.53 \mathrm{E}-05$ & 0.0011 \\
cg02206852 & PROCA1 & 52 & NUFIP2 & 0.0084 & 0.0022 & $1.06 \mathrm{E}-04$ & 0.0055 \\
cg02206852 & PROCA1 & 52 & GIT1 & 0.0080 & 0.0023 & $6.11 \mathrm{E}-04$ & 0.0318 \\
cg02885771 & LTV1 & 11 & VDAC1P8 & 0.0096 & 0.0033 & $3.51 \mathrm{E}-03$ & 0.0386 \\
cg07148038 & TNXB & 89 & ATP6V1G2 & 0.0074 & 0.0021 & $3.79 \mathrm{E}-04$ & 0.0337 \\
cg07148038 & TNXB & 89 & STK19B & 0.0035 & 0.0010 & $3.77 \mathrm{E}-04$ & 0.0335 \\
cg08065963 & & 12 & ABAT & 0.0127 & 0.0034 & $1.85 \mathrm{E}-04$ & 0.0022 \\
cg20939319 & TEX15 & 10 & SARAF & -0.0029 & 0.0010 & $3.36 \mathrm{E}-03$ & 0.0336 \\
cg22127773 & KDM6B & 80 & TMEM88 & 0.0011 & 0.0003 & $1.82 \mathrm{E}-04$ & 0.0146 \\
cg23396786 & SFXN5 & 18 & CYP26B1 & 0.0024 & 0.0008 & $1.78 \mathrm{E}-03$ & 0.0321 \\
cg25105536 & KLHL32 & 4 & KLHL32 & -0.0004 & 0.0002 & $5.52 \mathrm{E}-03$ & 0.0221 \\
\hline
\end{tabular}


Table 4 Overview of studies reporting results of differential DNA methylation with lung function or COPD in whole blood

\begin{tabular}{|c|c|c|c|c|c|}
\hline Study & Study population & Trait & $\begin{array}{l}\text { Adjustment } \\
\text { included } \\
\text { in model }\end{array}$ & $\begin{array}{l}\text { DNA methylation } \\
\text { platform }\end{array}$ & $\begin{array}{l}\text { Number of } \\
\text { CpG-sites } \\
\text { available for } \\
\text { comparison }\end{array}$ \\
\hline $\begin{array}{l}\text { Epigenome-wide } \\
\text { association study of } \\
\text { lung function level } \\
\text { and its change } \\
\text { Imboden et al., } 2019 \text { [17] }\end{array}$ & $\begin{array}{l}\text { Discovery-replication approach. } \\
\text { Discovery included } 3 \text { cohorts } \\
(N=2043) \text { and replication included } \\
7 \text { cohorts (Adult: } N=3327 \text {, } \\
\text { Childhood: } N=420 \text { ) } \\
\text { - Smoking status: self-reported, } \\
\text { subjects with and without smoking } \\
\text { history; never smokers only }\end{array}$ & $\begin{array}{l}\text { - } \mathrm{FEV}_{1} \\
\text { - FVC } \\
\text { - FEV }{ }_{1} / \mathrm{FVC} \\
\text { Analyses were performed } \\
\text { twice: with and without } \\
\text { adjustment for smoking status } \\
\text { and pack years }\end{array}$ & $\begin{array}{l}\text { - Age } \\
\text { - } \text { Age }^{2} \\
\text { - Height } \\
\text { - Height }{ }^{2} \\
\text { deviation } \\
\text { - Sex } \\
\text { - Sex Age, } \\
\text { Age }^{2} \\
\text { height, } \\
\text { Height }^{2} \\
\text { deviation } \\
\text { - Education } \\
\text { - BMl } \\
\text { - Spirometer } \\
\text { type } \\
\text { - Study } \\
\text { Center } \\
\text { - Blood cell } \\
\text { composition }\end{array}$ & $\begin{array}{l}\text { Discovery: Illumina } \\
\text { Infinium Human } \\
\text { Methylation } 450 \mathrm{~K} \\
\text { BeadChip and EPIC } \\
\text { BeadChip } \\
\text { Replication: various } \\
\text { arrays for the } \\
\text { discovery-identified } \\
\text { CpG-sites only }\end{array}$ & $\begin{array}{l}\text { Without } \\
\text { smoking } \\
\text { adjustment: } \\
56^{\mathrm{a}} \\
\text { With } \\
\text { smoking } \\
\text { adjustment: } \\
12^{\mathrm{a}} \\
\text { Never } \\
\text { smokers: } 8 \\
\text { (from } \\
\text { discovery). } \\
\text { None of the } \\
\text { CpG sites } \\
\text { were } \\
\text { replicated }\end{array}$ \\
\hline $\begin{array}{l}\text { No association } \\
\text { between DNA methylation } \\
\text { and COPD in never } \\
\text { and current smokers } \\
\text { De Vries et al., } 2018 \text { [16] }\end{array}$ & $\begin{array}{l}\text { Non-random selection from } \\
\text { LifeLines cohort ( } N=1561 \text { subjects) } \\
\text { - Smoking status: Stratified for smoking } \\
\text { ( } 658 \text { smokers and } 903 \text { never smokers) }\end{array}$ & $\begin{array}{l}\text { - } \mathrm{COPD} \\
\text { (defined as } \mathrm{FEV}_{1} / \mathrm{FVC} \leq 0.7 \text { ) }\end{array}$ & $\begin{array}{l}\text { - Sex } \\
\text { - Age } \\
\text { - Pack years } \\
\quad \text { (in smoking } \\
\text { stratified } \\
\text { analysis) } \\
\text { - Batch effects } \\
\text { - Blood cell } \\
\text { composition }\end{array}$ & $\begin{array}{l}\text { Illumina Infinium } \\
\text { Human } \\
\text { Methylation450K } \\
\text { BeadChip array } \\
\text { - Number of } \\
\text { included probes: } \\
\text { 420,938 }\end{array}$ & $\begin{array}{l}\text { Smokers: } \\
19492^{b} \\
\text { Never } \\
\text { smokers: } \\
\text { 19393 }^{b}\end{array}$ \\
\hline $\begin{array}{l}\text { Lung function discordance } \\
\text { in monozygotic twins and } \\
\text { ssociated differences in } \\
\text { blood DNA methylation } \\
\text { Bolund et al., } 2017 \text { [11] }\end{array}$ & $\begin{array}{l}\text { Sub-population of twins from the } \\
\text { Middle-Aged Danish Twin (MADT) } \\
\text { study ( } N=169 \text { twin pairs) } \\
\text { - Smoking status: subjects with and } \\
\text { without smoking history }\end{array}$ & $\begin{array}{l}\text { Intra-pair difference in z-score } \\
\text { calculated as "superior" minus } \\
\text { "inferior" twin at baseline and } \\
\text { during follow-up period for: } \\
\text { - FEV } 1 \\
\text { - FVC } \\
\text { - FEV } 1 / \text { FVC }\end{array}$ & $\begin{array}{l}\text { - Sex } \\
\text { - Age } \\
\text { - BMI } \\
\text { - Pack years } \\
\text { - Smoking } \\
\text { status at } \\
\text { follow-up } \\
\text { - Blood cell } \\
\text { composition } \\
\text { Intra-pair } \\
\text { difference } \\
\text { was } \\
\text { calculated for } \\
\text { all the } \\
\text { variables }\end{array}$ & $\begin{array}{l}\text { Illumina Infinium } \\
\text { Human } \\
\text { Methylation450K } \\
\text { BeadChip array } \\
\text { - Number of } \\
\text { included probes: } \\
\text { 453,014 }\end{array}$ & $37^{a}$ \\
\hline $\begin{array}{l}\text { Epigenome-wide association } \\
\text { study of chronic obstructive } \\
\text { pulmonary disease and lung } \\
\text { function in Koreans } \\
\text { Lee et al., } 2017 \text { [12] }\end{array}$ & $\begin{array}{l}\text { Sample of Korean COPD cohort } \\
\text { ( } N=100 \text { subjects) } \\
\text { - Smoking status: subjects with } \\
\text { and without smoking history }\end{array}$ & $\begin{array}{l}\text { - COPD status } \\
\text { (defined as } \mathrm{FEV}_{1} / \mathrm{FVC}<0.7 \text { ) } \\
\text { - } \mathrm{FEV}_{1} \\
\text { - FVC } \\
\text { - } \mathrm{FEV}_{1} / \mathrm{FVC}\end{array}$ & $\begin{array}{l}\text { - Sex } \\
\text { - Age } \\
\text { - Height } \\
\text { - Smoking } \\
\text { status } \\
\text { - Pack years } \\
\text { - Blood cell } \\
\text { composition }\end{array}$ & $\begin{array}{l}\text { Illumina Infinium } \\
\text { Human } \\
\text { Methylation450K } \\
\text { BeadChip array } \\
\text { - Number of } \\
\text { included probes: } \\
\text { 402,508 }\end{array}$ & $16^{\mathrm{a}}$ \\
\hline $\begin{array}{l}\text { Differential DNA methylation } \\
\text { marks and gene comethylation } \\
\text { of COPD in African-Americans } \\
\text { with COPD exacerbations } \\
\text { Busch et al., } 2016 \text { [13] }\end{array}$ & $\begin{array}{l}\text { Sample of PA-SCOPE AA } \\
\text { study population } \\
\text { ( } N=362 \text { subjects) } \\
\text { - Smoking status: smokers } \\
>20 \text { pack years }\end{array}$ & $\begin{array}{l}\text { - COPD } \\
\text { (defined as } \mathrm{FEV}_{1} / \mathrm{FVC} \leq 0.7 \\
\text { and } \mathrm{FEV}_{1} \leq 80 \% \text { ) }\end{array}$ & $\begin{array}{l}\text { - Sex } \\
\text { - Age } \\
\text { - Pack years } \\
\text { - Batch } \\
\text { number } \\
\text { - Blood cell } \\
\text { composition }\end{array}$ & $\begin{array}{l}\text { Illumina Infinium } \\
\text { Human } \\
\text { Methylation27K } \\
\text { BeadChip array } \\
\text { - Number of } \\
\text { included probes: } \\
\text { 19,302 }\end{array}$ & $12^{a}$ \\
\hline $\begin{array}{l}\text { The epigenetic clock is } \\
\text { correlated with physical } \\
\text { and cognitive fitness } \\
\text { in the Lothian Birth Cohort } \\
\text { Marioni et al., } 2015 \text { [15] }\end{array}$ & $\begin{array}{l}\text { The Lothian Birth Cohort } \\
\text { of } 1936 \\
\text { ( } N=1091) \\
\text { - Smoking status: self-reported, } \\
\text { subjects with and without } \\
\text { smoking history }\end{array}$ & $-\mathrm{FEV}_{1}$ & $\begin{array}{l}\text { - Sex } \\
\text { - Age } \\
\text { - Height } \\
\text { - Smoking } \\
\text { status } \\
\text { - Blood cell } \\
\text { composition }\end{array}$ & $\begin{array}{l}\text { Illumina Infinium } \\
\text { Human } \\
\text { Methylation450K } \\
\text { BeadChip array } \\
\text { - Number of } \\
\text { included probes: } \\
\text { 450,726 }\end{array}$ & $2^{a}$ \\
\hline
\end{tabular}


Table 4 Overview of studies reporting results of differential DNA methylation with lung function or COPD in whole blood (Continued)

\begin{tabular}{|c|c|c|c|c|c|}
\hline Study & Study population & Trait & $\begin{array}{l}\text { Adjustment } \\
\text { included } \\
\text { in model }\end{array}$ & $\begin{array}{l}\text { DNA methylation } \\
\text { platform }\end{array}$ & $\begin{array}{l}\text { Number of } \\
\text { CpG-sites } \\
\text { available for } \\
\text { comparison }\end{array}$ \\
\hline $\begin{array}{l}\text { Variable DNA methylation } \\
\text { is associated with } \\
\text { chronic obstructive } \\
\text { pulmonary disease and } \\
\text { lung function } \\
\text { Qiu et al., } 2012 \text { [10] }\end{array}$ & $\begin{array}{l}\text { Test-replication approach in } 2 \\
\text { family-based cohorts } \\
\text { ( N=1085 and } 369 \text { subjects) } \\
\text { - Smoking status: subjects with } \\
\text { and without smoking history }\end{array}$ & $\begin{array}{l}\text { - } \mathrm{COPD} \text { status }\left(\mathrm{FEV}_{1} / \mathrm{FVC} \leq 0.7\right. \\
\left.\text { and } \mathrm{FEV}_{1} \leq 70 \%\right) \\
\text { - } \mathrm{FEV}_{1} / \mathrm{FVC} \\
-\mathrm{FEV}_{1}\end{array}$ & $\begin{array}{l}\text { - Random } \\
\text { family effect }\end{array}$ & $\begin{array}{l}\text { Illumina Infinium } \\
\text { Human } \\
\text { Methylation27K } \\
\text { BeadChip array } \\
\text { - Number of } \\
\text { included probes: } \\
\text { 26,485 }\end{array}$ & $349^{\mathrm{a}}$ \\
\hline $\begin{array}{l}\text { Epigenome-wide scans } \\
\text { identify differentially } \\
\text { methylated regions for } \\
\text { age and age-related } \\
\text { phenotypes in a healthy } \\
\text { ageing population } \\
\text { Bell et al., } 2012 \text { [14] }\end{array}$ & $\begin{array}{l}\text { Sample of the TwinsUK cohort } \\
\text { ( } N=172 \text { female twin pairs) } \\
\text { - Smoking status: unknown }\end{array}$ & $\begin{array}{l}\text { - FEV } \\
\text { - FVC }\end{array}$ & $\begin{array}{l}\text { - Age } \\
\text { - Batch effects }\end{array}$ & $\begin{array}{l}\text { Illumina Infinium } \\
\text { Human } \\
\text { Methylation27K } \\
\text { BeadChip array } \\
\text { - Number of } \\
\text { included probes: } \\
24,641\end{array}$ & $1^{a}$ \\
\hline
\end{tabular}

COPD Chronic Obstructive Pulmonary Disease, FEV 1 Forced Expiratory Volume in $1 \mathrm{~s}$, FVC Forced Expiratory Capacity

${ }^{a} \mathrm{CpG}$-sites obtained from the online available data

${ }^{\mathrm{b}} \mathrm{CpG}$-sites selected at nominal $p$-value $<0.05$ available from self-performed analyses

associated with DNA methylation levels at the 9 different CpG-sites (Table 3). DNA methylation at cg25105536, annotated to KLHL32, was significantly associated with gene expression levels of KLHL32. DNA methylation levels at cg08065963, located in the intergenic region on chromosome 16 and not yet annotated to a gene, showed a significant association with gene expression levels of 4-Aminobutyrate Aminotransferase $(A B A T)$. For the other 7 CpG-sites, DNA methylation levels were associated with gene expression levels of one or two genes other than the previously annotated genes. An overview of the association between DNA methylation and gene expression levels of all genes can be found in Additional file 3: Table S3.

\section{Discussion}

This study is the first large general population-based EWA study on lung function in never smokers. So far, virtually all EWA studies on the origin of COPD included subjects with a history of cigarette smoking. As a consequence, these studies mainly addressed the origins of COPD in response to smoking. It is unclear if the results of these studies help to explain the etiology of COPD or rather explain the contribution of cigarette smoke towards the disease. Therefore, our study importantly contributes to the current understanding of COPD in never smokers.

We identified $36 \mathrm{CpG}$-sites that were significantly associated with $\mathrm{FEV}_{1} / \mathrm{FVC}$ at $p$-value below 0.0001 . The top hit of our meta-analysis, cg10012512, is located in the intergenic region of chromosome 7q36.3. It is therefore not possible to speculate on the functional effect of differences in DNA methylation at this specific CpG-site and how these differences may affect $\mathrm{FEV}_{1} / \mathrm{FVC}$. While associations found with an eQTM analysis may help to get more insight in the function of a CpG-site, our eQTM analysis did not reveal any nominal significant associations for cg10012512. However, this CpG-site was differentially methylated between never smokers and current smokers [23]. Presumably, this CpG-site does also respond to other inhaled deleterious substances, which in turn affects lung function. The second top hit, cg02885771 located on chromosome 6q24.2 is annotated LTV1. Previously, this CpG-site has been associated with asthma in airway epithelial cells [24] and LTV1 was shown to be expressed in lung tissue in the Genotype Tissue Expression (GTEx) project. Although studies in yeast describe $L T V 1$ as a conserved $40 S$-associated biogenesis factor that functions in small subunit nuclear export, a specific role for $L T V 1$ in respiratory diseases is not known [25]. The third top hit, cg25105536, is annotated to KLHL32 on chromosome 6q16.1 and we found a significant association between DNA methylation levels of cg25105536 and gene expression levels of KLHL32. The function of KLHL32 is poorly understood, however, four genetic variants in the KLHL32 gene have been associated with $\mathrm{FEV}_{1}$ and $\mathrm{FEV}_{1} / \mathrm{FVC}$ in African American subjects with COPD and a history of smoking [26]. Notwithstanding the fact that these associations were only identified in a specific group, it might suggest a role for $K L H L 32$ in the respiratory system. Next to $K L H L 32$, we found that gene expression levels of 10 additional genes were significantly associated with DNA methylation levels at one of the 36 CpG-sites. cg08065963, which was not yet annotated to a gene, was significantly associated with 4-Aminobutyrate Aminotransferase (ABAT). Interestingly, a role for $A B A T$ in COPD has not been described before. The remaining nine genes were other genes than the annotated genes of the particular CpG-sites. This suggest that the CpG-sites may also regulate distant genes within a region of $2 \mathrm{MB}$, which complicates the functional assessment of differences in DNA methylation even further. 
Table 5 Overview of CpG location, gene annotation, gene function and literature comparison of the top 36 CpG-sites of the meta analysis

\begin{tabular}{|c|c|c|c|c|}
\hline CpG-site & CpG location & Gene annotation & Gene function & $\begin{array}{l}\text { Previously associated } \\
\text { with lung function }\end{array}$ \\
\hline cg10012512 & 7:157224041 & Intergenic & $N A$ & Yes $^{a}$ \\
\hline cg02885771 & 6:144163654 & LTV1 & Involved in ribosome biogenesis & No \\
\hline $\operatorname{cg} 25105536$ & 6:97372436 & KLHL32 & Only described as protein coding gene & No \\
\hline cg20102034 & 2:74653166 & RTKN & $\begin{array}{l}\text { Negative regulator of GTPase activity of } \\
\text { Rho proteins }\end{array}$ & Yes $^{\mathrm{a}}$ \\
\hline cg03703840 & 11:93394809 & KIAA1731 & $\begin{array}{l}\text { Mediating of centriole-to-centrosome } \\
\text { conversion at late mitosis }\end{array}$ & No \\
\hline cg21614201 & 4:119888794 & SYNPO2 & Only described as protein coding gene & No \\
\hline cg07957088 & 20:62196387 & PRIC285 & $\begin{array}{l}\text { Nuclear transcriptional co-activator for } \\
\text { peroxisome proliferator activated } \\
\text { receptor alpha }\end{array}$ & Yes $^{\mathrm{a}}$ \\
\hline cg05304461 & 1:11019377 & C1orf127 & Only described as protein coding gene & No \\
\hline cg11749902 & 8:41093619 & Intergenic & NA & Yes $^{\mathrm{a}}$ \\
\hline cg02207312 & 11:60674164 & PRPF19 & Involved in cell survival and DNA repair & No \\
\hline cg19734370 & $17: 78444348$ & NPTX1 & $\begin{array}{l}\text { Exclusively localized to the nervous system } \\
\text { as binding protein for taipoxin }\end{array}$ & $Y_{e s}{ }^{a}$ \\
\hline cg03077331 & 17:80693076 & FN3K & Catalyzes the phosphorylation of fructosamines & Yes $^{\mathrm{a}}$ \\
\hline cg18387671 & 17:27920246 & ANKRD13B & Only described as protein coding gene & Yes $^{\mathrm{a}}$ \\
\hline cg03224276 & 16:72829831 & ZFHX3 & Regulates myogenic and neuronal differentiation & No \\
\hline cg02137691 & 4:1805671 & FGFR3 & Involved in bone development and maintenance & No \\
\hline $\operatorname{cg} 25884324$ & 15:91482502 & UNC45A & $\begin{array}{l}\text { Regulator of the progesterone receptor } \\
\text { chaperoning pathway }\end{array}$ & No \\
\hline cg27158523 & 6:149867355 & PPIL4 & $\begin{array}{l}\text { Involved in protein folding, immunosuppression } \\
\text { and infection of HIV-1 virions }\end{array}$ & Yes $^{\mathrm{a}}$ \\
\hline cg01157143 & 11:19478542 & NAV2 & Plays a role in cellular growth and migration & No \\
\hline cg07160694 & 14:69619856 & DCAF5 & Only described as protein coding gene & No \\
\hline cg22127773 & 17:7754785 & KDM6B & $\begin{array}{l}\text { Demethylation of di- or tri-methylated lysine } \\
27 \text { of histone } \mathrm{H3}\end{array}$ & Yes $^{\mathrm{a}}$ \\
\hline cg20939319 & 8:30707701 & TEX15 & Involved in cell cycle processes of spermatocytes & No \\
\hline cg02206852 & 17:27030540 & PROCA1 & Only described as protein coding gene & No \\
\hline cg17075019 & 10:79541650 & Intergenic & NA & $Y_{e s}{ }^{a}$ \\
\hline $\operatorname{cg} 25556432$ & 2:239628926 & Intergenic & NA & $Y_{e s}{ }^{a}$ \\
\hline cg22742965 & 2:192891657 & TMEFF2 & $\begin{array}{l}\text { Cellular context-dependent oncogene or } \\
\text { tumor suppressor }\end{array}$ & Yes \\
\hline cg16734845 & 15:44781962 & CTDSPL2 & Only described as protein coding gene & No \\
\hline cg09108394 & 16:23850106 & PRKCB & $\begin{array}{l}\text { As kinase involved in diverse cellular } \\
\text { signaling pathways }\end{array}$ & No \\
\hline $\operatorname{cg} 10034572$ & 2:160921789 & Intergenic & NA & No \\
\hline cg20066227 & 10:16564552 & CIQL3 & Only described as protein coding gene & No \\
\hline cg07148038 & $6: 32061160$ & $T N X B$ & $\begin{array}{l}\text { Anti-adhesive protein involved in matrix } \\
\text { maturation during wound healing }\end{array}$ & Yes $^{\mathrm{a}}$ \\
\hline cg23396786 & 2:73299151 & SFXN5 & Only described as protein coding gene & Yes $^{\mathrm{a}}$ \\
\hline cg06218079 & 17:80834228 & $T B C D$ & $\begin{array}{l}\text { As co-factor } D \text { involved in the correct } \\
\text { folding of beta-tubulin }\end{array}$ & No \\
\hline cg06982745 & 10:72454006 & ADAMTS14 & $\begin{array}{l}\text { The matured enzyme is involved in the } \\
\text { formation of collagen fibers }\end{array}$ & No \\
\hline cg05946118 & 16:8985638 & Intergenic & NA & Yes $^{\mathrm{a}}$ \\
\hline cg08065963 & 16:8985593 & Intergenic & NA & Yes $^{\mathrm{a}}$ \\
\hline cg12064372 & 12:30948792 & Intergenic & $N A$ & $\mathrm{Yes}^{\mathrm{a}}$ \\
\hline
\end{tabular}

${ }^{a}$ Only observed in study by de Vries et al. in never smokers; Gene function obtained by www.genecards.org 
To the best of our knowledge, there are eight studies in literature describing the association between DNA methylation and lung function (Table 4). Six of these studies included both subjects with and without a history of cigarette smoking and, except for the study by Qui et al., adjusted for smoking status in the statistical analysis. In addition, the recent study by Imboden et al. performed analyses with and without adjustment for smoking status and pack years. Altogether, these seven studies identified 462 unique CpG-sites. Interestingly, none of the $36 \mathrm{CpG}$-sites from our meta-analysis in never smokers were among these 462 previously identified CpG-sites (Table 5). Apparently these 36 CpG-sites are only associated with lung function level in never smokers. The fact that 17 CpG-sites (47\%) were associated at nominal $p$-value $<0.05$ with COPD (dichotomously defined as the ratio of $\mathrm{FEV}_{1} / \mathrm{FVC}$ below $70 \%$ ) in our previously EWAS stratified for never smoking, further underscores this assumption [16]. There is, however, one exception, since cg22742965, annotated to Transmembrane Protein With EGF Like And Two Follistatin Like Domains 2 (TMEFF2), was also significantly associated with COPD in smokers. Most likely, this CpG-site shows a general response to inhaled deleterious substances such as cigarette smoke and other yet unknown substances.

Assuming that the observed differential DNA methylation at the majority of the CpG-sites in our study occurs without exposure to smoking, the question arises why this differential DNA methylation is observed. One possible explanation may be that other factors within the environment such as air pollution and job-related exposures are responsible for the observed differences in DNA methylation. Recently, we studied the epigenome-wide association between DNA methylation and exposure to air pollution and job-related exposures in a selection of the LifeLines population cohort including both never and current smokers [19, 27]. While we did find significant associations, none of them were replicated in independent cohorts. Additional analyses in never smokers for this paper did not reveal novel associations between DNA methylation and environmental exposures (Additional file 4: Table S4 and Additional file 5: Figure S1). This might potentially be due to lack of power, since only a small percentage of the subjects that have never smoked in the LL COPD\&C cohort have been exposed to environmental exposures. Moreover, exposure levels to air pollution in the LL COPD\&C are relatively low compared to the average Dutch levels determined within the 2012 Dutch national health survey as described by Strak et al [28]. Next to environmental exposures, another explanation may be that a reduced lung function level precedes the differences in DNA methylation. However, with the cross-sectional design of this study, we cannot derive conclusions on the direction of the association and causality. Large longitudinal studies are required to investigate causality between DNA methylation and $\mathrm{FEV}_{1} / \mathrm{FVC}$. Moreover, this will give the opportunity to investigate if low levels of $\mathrm{FEV}_{1}$ and decline in $\mathrm{FEV}_{1}$ over the years is associated with DNA methylation in never smokers.

\section{Conclusions}

With this study we show that epigenetics indeed may be associated with $\mathrm{FEV}_{1} / \mathrm{FVC}$ in subjects who never smoked. Moreover, since 35 out of the 36 identified CpG-sites are unique for never smokers, our data suggest that factors other than smoking affect $\mathrm{FEV}_{1} / \mathrm{FVC}$ via DNA methylation.

\section{Supplementary information}

Supplementary information accompanies this paper at https://doi.org/10 1186/s12931-019-1222-8.

Additional file 1: Table S1. Overview of all CpG-sites associated with FEV1/FVC at nominal $p$-value of 0.05.

Additional file 2: Table S2. Sensitivity analysis of the association of the top 36 CpG-sites with $\mathrm{FEV}_{1} / \mathrm{FVC}$ in 659 subjects that were not exposed to environmental tobacco smoke.

Additional file 3: Table S3. Overview of association between DNA methylation and gene expression.

Additional file 4: Table S4. Results of the association between 36 top CpG-sites identified from the meta-analysis and A: environmental exposures and B: air pollution measurements.

Additional file 5: Figure S1: Forest plots of the associations between DNA methylation and environmental exposures.

\section{Abbreviations}

ATS: American Thoracic Society; BIOS: Biobank-based Integrative Omics Studies; COPD: Chronic Obstructive Pulmonary Disease; CpG: Cytosinephosphate-Guanine; DNA: Deoxyribonucleic acid; eQTM: Expression Quantitative Trait Methylation; ERS: European Respiratory Society; ETS: Environmental tobacco smoke; EWAS: Epigenome-wide association

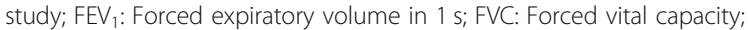
GTEx: Genotype tissue expression

\section{Acknowledgements}

The Biobank-Based Integrative Omics Studies (BIOS) Consortium is funded by BBMRI-NL, a research infrastructure financed by the Dutch government (NWO 184.021.007).

\section{Authors' contributions}

$M d V, A Z, L L, G G B, N A, C M v D$, JMV, and HMB were involved in conception and design of the research. MdV, IN, and DAvdP performed the analyses. $M d V$ and $H M B$ interpreted the results. MdV prepared figures and drafted the manuscript. $H M B, I N$, and JMV critically reviewed and revised the manuscript. All authors read and approved the final version of the manuscript.

\section{Funding}

This work was supported by consortium grant number 4.1.13.007 of the Lung foundation Netherlands. The LifeLines initiative has been made possible by funds from FES (Fonds Economische Structuurversterking), SNN (Samenwerkingsverband Noord Nederland) and REP (Ruimtelijk Economisch Programma).

\section{Availability of data and materials}

The datasets and/or analyzed during the current study are available from the corresponding authors on reasonable request. Summary statistics of the meta-analysis and the four individual EWAS studies with nominal $p$-value of 0.05 have been made freely available as Additional file. 


\section{Ethics approval and consent to participate}

LifeLines population-based cohort study

Written informed consents was provided by all included subjects and the study was approved by the Medical Ethics Committee of the University Medical Center Groningen (2007/152).

The Rotterdam Study

Written informed consents to participate in the study and to obtain information from their treating physicians was provided by all participants. The study has been approved by the Medial Ethics Committee of the Erasmus Medical Center and by the Ministry of Health, Welfare and Sport of the Netherlands, implementing the Population Studies Act: Rotterdam Study.

\section{Consent for publication}

Not applicable

\section{Competing interests}

The authors declare that they have no competing interests.

\section{Author details}

${ }^{1}$ University of Groningen, University Medical Center Groningen, Department of Epidemiology, Hanzeplein 1, 9713 GZ Groningen, The Netherlands. ${ }^{2}$ University of Groningen, University Medical Center Groningen, Groningen Research Institute for Asthma and COPD (GRIAC), Groningen, The Netherlands. ${ }^{3}$ Department of Epidemiology, Erasmus Medical Center, Rotterdam, The Netherlands. ${ }^{4}$ University of Groningen, University Medical Center Groningen, Department of Genetics, Groningen, The Netherlands. ${ }^{5}$ Department of Bioanalysis, FFW, Ghent University, Ghent, Belgium. ${ }^{6}$ Department of Respiratory Medicine, Ghent University Hospital, Ghent, Belgium. 'Department of Respiratory Medicine, Erasmus Medical Center, Rotterdam, The Netherlands. ${ }^{8}$ BIOS Consortiumhttps://www.bbmri.nl/ acquisition-use-analyze/bios.

Received: 9 July 2019 Accepted: 22 October 2019

Published online: 02 December 2019

\section{References}

1. From the Global Strategy for the Diagnosis, Management and Prevention of COPD, Global Initiative for Chronic Obstructive Lung Disease (GOLD) 2015. Available from: http://wnw.goldcopd.org/.

2. Salvi SS, Barnes PJ. Chronic obstructive pulmonary disease in non-smokers. Lancet. 2009:374(9691):733-43.

3. van der Plaat DA, de Jong K, Lahousse L, Faiz A, Vonk JM, van Diemen CC, et al. Genome-wide association study on the FEV1/FVC ratio in never-smokers identifies HHIP and FAM13A. J Allergy Clin Immunol. 2017;139(2):533-40.

4. de Jong $\mathrm{K}$, Boezen HM, Kromhout $\mathrm{H}$, Vermeulen R, Postma DS, Vonk JM. Association of occupational pesticide exposure with accelerated longitudinal decline in lung function. Am J Epidemiol. 2014;179(11):1323-30.

5. de Jong K, Vonk JM, Timens W, Bosse Y, Sin DD, Hao K, et al. Genome-wide interaction study of gene-by-occupational exposure and effects on FEV1 levels. J Allergy Clin Immunol. 2015;136(6):1664-72.e1-14.

6. Hobbs BD, de Jong K, Lamontagne M, Bosse Y, Shrine N, Artigas MS, et al. Genetic loci associated with chronic obstructive pulmonary disease overlap with loci for lung function and pulmonary fibrosis. Nat Genet. 2017:49(3):426-32.

7. Jirtle RL, Skinner MK. Environmental epigenomics and disease susceptibility. Nat Rev Genet. 2007;8(4):253-62.

8. Yang IV, Lozupone CA, Schwartz DA. The environment, epigenome, and asthma. J Allergy Clin Immunol. 2017;140(1):14-23.

9. Jones PA. Functions of DNA methylation: islands, start sites, gene bodies and beyond. Nat Rev Genet. 2012;13(7):484-92.

10. Qiu W, Baccarelli A, Carey VJ, Boutaoui N, Bacherman H, Klanderman B, et al. Variable DNA methylation is associated with chronic obstructive pulmonary disease and lung function. Am J Respir Crit Care Med. 2012;185(4):373-81.

11. Bolund ACS, Starnawska A, Miller MR, Schlunssen V, Backer V, Borglum AD, et al. Lung function discordance in monozygotic twins and associated differences in blood DNA methylation. Clin Epigenetics. 2017:9:132-017-0427-2 eCollection 2017.

12. Lee MK, Hong Y, Kim SY, Kim WJ, London SJ. Epigenome-wide association study of chronic obstructive pulmonary disease and lung function in Koreans. Epigenomics. 2017:9(7):971-84.

13. Busch R, Qiu W, Lasky-Su J, Morrow J, Criner G, DeMeo D. Differential DNA methylation marks and gene comethylation of COPD in African-Americans with COPD exacerbations. Respir Res. 2016;17(1):143-016-0459-8.
14. Bell J, Tsai PC, Yang TP, Pidsley R, Nisbet J, Glass D, et al. Epigenome-wide scans identify differentially methylated regions for age and age-related phenotypes in a healthy ageing population. PLoS Genet. 2012;8(4):e1002629.

15. Marioni RE, Shah S, McRae AF, Ritchie SJ, Muniz-Terrera G, Harris SE, et al. The epigenetic clock is correlated with physical and cognitive fitness in the Lothian birth cohort 1936. Int J Epidemiol. 2015;44(4):1388-96.

16. de Vries $\mathrm{M}$, van der Plaat $\mathrm{DA}$, Vonk JM, Boezen HM. No association between DNA methylation and COPD in never and current smokers. BMJ Open Respir Res. 2018;5(1):e000282-2018-000282 eCollection 2018.

17. Imboden M, Wielscher M, Rezwan FI, Amaral AFS, Schaffner E, Jeong A, et al. Epigenome-wide association study of lung function level and its change. Eur Respir J. 2019;54(1)

18. Scholtens S, Smidt N, Swert MA, Bakker SJ, Dotinga A, Vonk JM, et al. Cohort profile: lifelines, a three-generation cohort study and biobank. Int J Epidemiol. 2015;44(4): $1172-80$.

19. van der Plaat DA, de Jong $K$, de Vries M, van Diemen CC, Nedeljkovic I, Amin N, et al. Occupational exposure to pesticides is associated with differential DNA methylation. Occup Environ Med. 2018;75(6):427-35.

20. Tigchelaar EF, Zhernakova A, Dekens JA, Hermes G, Baranska A, Mujagic Z, et al. Cohort profile: LifeLines DEEP, a prospective, general population cohort study in the northern Netherlands: study design and baseline characteristics. BMJ Open. 2015;5(8):e006772-2014-006772

21. Ikram MA, Brusselle GGO, Murad SD, van Duijn $\mathrm{CM}$, Franco OH, Goedegebure A, et al. The Rotterdam study: 2018 update on objectives, design and main results. Eur J Epidemiol. 2017;32(9):807-50.

22. Ligthart S, Steenaard RV, Peters MJ, van Meurs JB, Sijbrands EI, Uitterlinden AG, et al. Tobacco smoking is associated with DNA methylation of diabetes susceptibility genes. Diabetologia. 2016:59(5):998-1006.

23. Joehanes R, Just AC, Marioni RE, Pilling LC, Reynolds LM, Mandaviya PR, et al. Epigenetic signatures of cigarette smoking. Circ Cardiovasc Genet. 2016;9(5):436-47.

24. Nicodemus-Johnson J, Myers RA, Sakabe NJ, Sobreira DR, Hogarth DK, Naureckas ET, et al. DNA methylation in lung cells is associated with asthma endotypes and genetic risk. JCl Insight. 2016;1 (20):e90151.

25. Merwin JR, Bogar LB, Poggi SB, Fitch RM, Johnson AW, Lycan DE. Genetic analysis of the ribosome biogenesis factor Ltv1 of Saccharomyces cerevisiae. Genetics. 2014; 198(3):1071-85

26. Lutz SM, Cho MH, Young K, Hersh CP, Castaldi PJ, McDonald ML, et al. A genome-wide association study identifies risk loci for spirometric measures among smokers of European and African ancestry. BMC Genet. 2015;16:138015-0299-4.

27. de Lichtenfels AJFC, van der Plaat DA, de Jong K, van Diemen CC, Postma DS, Nedeljkovic I, et al. Long-term air pollution exposure, genome-wide DNA methylation and lung function in the lifelines cohort study. Environ Health Perspect. 2018;126(2):027004.

28. Strak M, Janssen N, Beelen R, Schmitz O, Vaartjes I, Karssenberg D, et al. Long-term exposure to particulate matter, $\mathrm{NO} 2$ and the oxidative potential of particulates and diabetes prevalence in a large national health survey. Environ Int. 2017;108:228-36.

\section{Publisher's Note}

Springer Nature remains neutral with regard to jurisdictional claims in published maps and institutional affiliations.

Ready to submit your research? Choose BMC and benefit from:

- fast, convenient online submission

- thorough peer review by experienced researchers in your field

- rapid publication on acceptance

- support for research data, including large and complex data types

- gold Open Access which fosters wider collaboration and increased citations

- maximum visibility for your research: over $100 \mathrm{M}$ website views per year

At $\mathrm{BMC}$, research is always in progress.

Learn more biomedcentral.com/submission 